79, 583 (1994).

11. P. Montalbini, J. Phytopathol. 134, 218 (1992); Riv Patol. Veg. 4, 81 (1994). Allopurinol (400 mM) in water was applied as a soil drench 8 days before either shift to LD conditions or application of INA.

12. Z. Chen, H. Silva, D. F. Klessig, Science 262, 1883 (1993); P. Sánchez-Casas and D. F. Klessig, Plant Physiol. 106, 1675 (1994). Compounds tested were 3-amino triazole $(0.2$ to $4 \mathrm{mM})$, which inhibits catalase and therefore may act to increase local $\mathrm{H}_{2} \mathrm{O}_{2}$ concentrations; catalase itself ( 1.2 to $120 \mathrm{U} / \mathrm{ml})$; and the oxygen radical scavenger Tiron (4,5-dihydroxy3,5-disulfonic acid; 1 to $10 \mathrm{mM}$ ) (Sigma)

13. INA $(0.4 \mathrm{mM}$ as $25 \%$ active compound and $75 \%$ wettable powder mix in water) and SA ( $2 \mathrm{mM}$ ) (Fig. 1) (9) were applied to imminent runoff as described (3)

14. J. T. Hancock and O. T. G. Jones, Biochem. J. 242 103 (1987). DPI was inoculated in $0.1 \%$ dimethyl sulfoxide.

15. C.-K. Auh and T. M. Murphy, Plant Physiol. 107, 1241 (1995); S. C. Dwyer, L. Legrendre, P. Low, T. L. Leto, Biochem. Biophys. Acta 1289, 231 (1995); T. Jabs et al., unpublished data.

16. V. B. O'Donnell, D. G. Tew, O. T. G. Jones, P. J. England, Biochem. J. 290, 41 (1993).

17. RNA (5 $\mu \mathrm{g}$ per lane) was isolated (10 leaves from three plants) and blots were prepared, probed, and washed as described [S. Kiedrowski, P. Kawalleck, K. Hahlbrock, I. E. Somssich, J. L. Dangl, EMBO J. 11, 4677 (1992)]. The probes used were PR-1 cDNA [S. Uknes et al., Plant Cell 5, 159 (1993)] and ESTs [T. Newman et al., Plant Physiol. 106, 1241 (1994)]. The ESTs were from the Arabidopsis Biological Resource Center, Ohio State University. EST identification numbers are as follows: B25XP, homologous to $P R X c b$ (GenBank accession number X71794): 90B13T7, GST (GenBank accession number T20657), and a type III GST, similar to an auxinregulated protein and GST clones [F. N. J. Droog, P J. J. Hooykaas, B. J. van der Zaal, Plant Physiol. 107, 11139 (1995)]. Other Arabidopsis GSTS described are class I (GST2 and PMA239×14). ESTs showing no difference in expression between $I s d 1$ and the wild type putatively encode Fe-SOD (34D9T 7); Cu/ Zn-SOD (2G11T7P and 92L6T7); Mn-SOD (105G4T7); Catalase I (35F2T7, 38C1T7, and 40A1T7); anionic lignin-forming peroxide (ATTS0592); cationic peroxidase (40H1T 7); P7 peroxidase (11B11T7); glutathione peroxidase (139F9T 7); and lipoxygenase I (92 H8T 7). The apparent lack of SA-induced PR-1 mRNA accumulation in wild-type leaves (Fig. 2D) is due to deliberate underexposure of the autoradiogram in order to visualize the stronger signals. Normal exposure clearly shows PR-1 mRNA accumulation.

18. D. Inze and M. Van Montagu, Curr. Opin. Biotechnol. 3, 153 (1995); M. C. Mehdy, Plant Physiol. 105, 467 (1994); C. J. Baker and E. W. Orlandi, Annu. Rev. Phytopathol. 33, 299 (1995).

19. J. G. Scandalios, Plant Physiol. 101, 7 (1993); S. Streller and G. Wingsle, Planta 192, 195 (1994).

20. Fast neutron-mutagenized /sd 1 seed was grown under SD conditions. Ten M2 seed lots from 200 M1 individuals were screened for wild-type plants after shift to LD conditions at 2 weeks of age. Lesion initiation in young seedlings is lethal. Loci defined by these suppressor mutants are named PHOENIX ( $p h x)$, after the mythological bird risen from its own ashes. M3 progeny of survivors were retested, and suppressors were categorized by segregation of the Isd1 phenotype in $F_{1}$ individuals and $F_{2}$ populations of backcrosses to $\mathrm{Ws}-0$ and $/ s d 1$. These analyses established that $p h \times 21$ is unlinked to $/ s d 1$, recessive to its wild-type allele, and has no obvious phenotype in combination with LSD1 (R. A. Dietrich et al., unpublished data). NBT staining after shift to LD conditions was also abolished (9)

21. G. Wu et al. Plant Cell 7, 1357 (1995); I. Apostol, P. F. Heinstein, P. S. Low, Plant Physiol. 99, 109 (1989); C. J. Baker, N. O'Neill, L. Keppler, E. W. Orlandi, Phytopathology 81, 1504 (1991); R. VeraEstrella, E. Blumwald, V. J. Higgins, Physiol. Mol. Plant Pathol. 42, 9 (1993); M. J. May, K. E. Hammond-Kosack, J. D. G. Jones, Plant Physiol. 110, 1367 (1996)
22. A. J. Enyedi, N. Yalpani, P. Silverman, I. Raskin, Proc. Natl. Acad. Sci. U.S.A. 89, 2480 (1992)

23. T. P. Delaney et al., Science 266, 1247 (1994); K Weyman et al., Plant Cell 7, 2013 (1995); H. Kauss and W. Jeblick, Plant Physiol. 108, 1171 (1995); H. Kauss, E. Theisinger-Hinkel, R. Mindermann, U. Conrath, Plant J. 2, 655 (1992); L. A. J. Mur et al. ibid. 9, 559 (1996); U. Neuenschwander et al., unpublished data.

24. These hypotheses suggest that the $/ s d 1$ mutation is a strong loss-of-function or null allele, and our preliminary characterization of a candidate gene supports this (R. A. Dietrich, M. H. Richberg, J. L. Dangl, unpublished data).

25. B. N. Ames, M. K. Shigenaga, T. M. Hagen, Proc Natl. Acad. Sci. U.S.A. 90, 7915 (1993); J. Busciglio and B. A. Yanker, Nature 378, 776 (1995); P. C Wong et al., Neuron 14, 1106 (1995); M. Wiedau Pazos et al., Science 271, 515 (1996); F. Morel, J. Doussiere, P. V. Vignais, Eur. J. Biochem. 201, 523 (1991).

26. We thank J. Ryals and S. Uknes for critical comments on the manuscript and the PR-1 cDNA, and U. Ringeisen (Köln) and S. Whitfield (Chapel Hill) for help in preparing figures. Supported by grants from the German Research Society's (Deutsche Forschungsgeimenschaft) "Arabidopsis" Focus Program (to J.L.D.) and the EEC-BIOTECH Project of Technological Priority (to J.L.D.) and by a MaxPlanck-Society fellowship to T.J.

21 March 1996; accepted 9 August 1996

\title{
Genetic Restriction of HIV-1 Infection and Progression to AIDS by a Deletion Allele of the CKR5 Structural Gene
}

\author{
Michael Dean, ${ }^{*}$ Mary Carrington, ${ }^{*}$ Cheryl Winkler,
} Gavin A. Huttley, Michael W. Smith, Rando Allikmets, James J. Goedert, Susan P. Buchbinder, Eric Vittinghoff, Edward Gomperts, Sharyne Donfield, David Vlahov, Richard Kaslow, Alfred Saah, Charles Rinaldo, Roger Detels, Hemophilia Growth and Development Study, Multicenter AIDS Cohort Study, Multicenter Hemophilia Cohort Study, San Francisco City Cohort, ALIVE Study, Stephen J. O’Brien†

The chemokine receptor 5 (CKR5) protein serves as a secondary receptor on CD4 ${ }^{+} \mathrm{T}$ lymphocytes for certain strains of human immunodeficiency virus-type 1 (HIV-1). The CKR5 structural gene was mapped to human chromosome 3p21, and a 32-base pair deletion allele (CKR5 32 ) was identified that is present at a frequency of $\sim 0.10$ in the Caucasian population of the United States. An examination of 1955 patients included among six well-characterized acquired immunodeficiency syndrome (AIDS) cohort studies revealed that 17 deletion homozygotes occurred exclusively among 612 exposed HIV-1 antibody-negative individuals (2.8 percent) and not at all in 1343 HIV-1-infected individuals. The frequency of $C K R 5$ deletion heterozygotes was significantly elevated in groups of individuals that had survived HIV-1 infection for more than 10 years, and, in some risk groups, twice as frequent as their occurrence in rapid progressors to AIDS. Survival analysis clearly shows that disease progression is slower in CKR5 deletion heterozygotes than in individuals homozygous for the normal CKR5 gene. The CKR5 32 deletion may act as a recessive restriction gene against HIV-1 infection and may exert a dominant phenotype of delaying progression to AIDS among infected individuals.

In all well-characterized epidemics there are individuals in the population that respond differently to the infectious agent ( 1 , 2 ). Although resistance to infection is the most common variable phenotype, variation in disease outcomes has also been observed. Epidemiologic studies have shown that inherited factors are involved in the risk of mortality from infectious agents (3, 4). The HIV-1 epidemic presents a critical challenge for the application of current genetic techniques to the study of host genetic variation for infection and susceptibility to infection. This problem is confounded in the studies of HIV-1 by the rapid rate of evolution of the virus (5-7). However, a number of groups have shown that specific alleles of the human lymphocyte antigen (HLA) locus are associated with different rates of progression from infection to an AIDS diagnosis (8). Yet little evidence for non-HLA loci regulating HIV-1 infection or AIDS progression has been reported, although it does seem likely that other host genetic factors would play a role in AIDS epidemiology $(8,9)$.

The recent demonstration that the chemokines RANTES, MIP- $1 \alpha$, and MIP-1 $\beta$ act as natural suppressors of HIV-1 infection (10) has focused attention on the role of these chemokines during HIV-1 infection and clinical pathogenesis. Feng et al. 
Table 1. AIDS cohorts studied. [A list of researchers and their affiliations for HGDS and MHCS are given in (52).]

\begin{tabular}{|c|c|c|c|c|c|c|c|}
\hline Study name & Acronym & Risk group & Enrollment & Participants & Sites $^{*}$ & $\begin{array}{l}\text { Principal } \\
\text { investigators }\end{array}$ & Reference \\
\hline $\begin{array}{l}\text { Hemophilia Growth and } \\
\text { Development Study }\end{array}$ & HGDS & Hemophiliacs & $1989-1990$ & 333 & 14 & $\begin{array}{l}\text { E. D. Gomperts, } \\
\text { M. W. Hilgartner, } \\
\text { W. K. Hoots, } \\
\text { S. M. Donfield }\end{array}$ & (31) \\
\hline $\begin{array}{l}\text { Multicenter Hemophila } \\
\text { Cohort Study }\end{array}$ & MHCS & Hemophiliacs & $1985-1990$ & 2472 & 10 & J. J. Goedert & (32) \\
\hline DC Gay Cohort Study & DCG & $\begin{array}{l}\text { Homosexual men } \\
\text { and intravenous } \\
\text { drug users } \dagger\end{array}$ & 1982 & 307 & 3 & $\begin{array}{l}\text { J. J. Goedert, } \\
\text { R. J. Biggar }\end{array}$ & (33) \\
\hline $\begin{array}{l}\text { Multicenter AIDS Cohort } \\
\text { Study }\end{array}$ & MACS & Homosexual men & 1984 & 5000 & 4 & $\begin{array}{l}\text { A. Munoz, } \\
\text { J. P. Phair, } \\
\text { R. Detels, } \\
\text { C. R. Rinaldo Jr., } \\
\text { A. J. Saah }\end{array}$ & (34) \\
\hline $\begin{array}{l}\text { San Francisco City Clinic } \\
\text { Cohort }\end{array}$ & SFCC & Homosexual men & $1978-1980$ & 6704 & 1 & S. P. Buchbinder & (35) \\
\hline $\begin{array}{l}\text { AIDS Link to the } \\
\text { Intravenous } \\
\text { Experience }\end{array}$ & ALIVE & $\begin{array}{l}\text { Intravenous drug } \\
\text { users }\end{array}$ & $1988-1990$ & 2958 & 1 & D. Vlahov & (36) \\
\hline
\end{tabular}

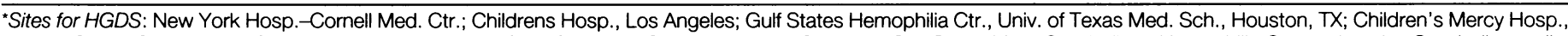

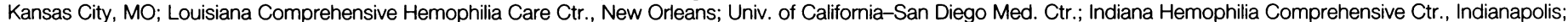

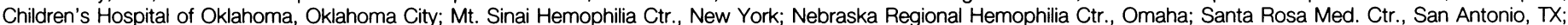

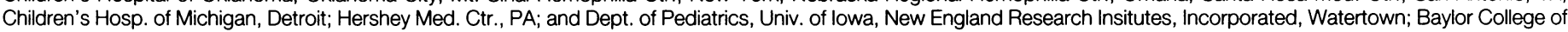

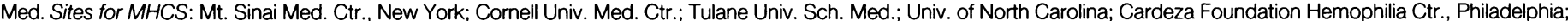

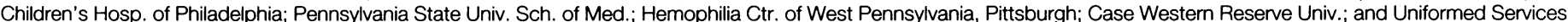

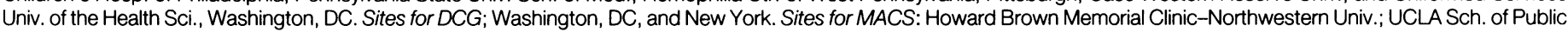

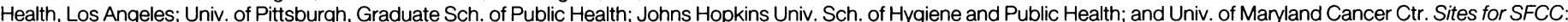

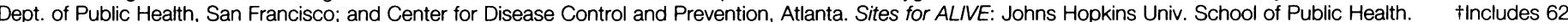
individuals from an intravenous drug use study.

(11) identified a chemokine receptor, fusin (12-14), as an HIV-1 entry cofactor (or co-receptor) with CD4 (15) for T cell linetropic strains. Several groups then showed that the cysteine-cysteine (C-C)-linked chemokine receptor CKR5 (also called CCCKR5, CCR5, and designated with gene

M. Dean, G. A. Huttley, R. Allikmets, S. J. O'Brien, Laboratory of Genomic Diversity, National Cancer Institute (NCl), Frederick, MD 21702-1201, USA

M. Carrington, C. Winkler, M. W. Smith, Intramural Research Support Program, Science Applications International Corporation Frederick, NCl, Frederick, MD $21702-$ 1201, USA

J. J. Goedert, Viral Epidemiology Branch, $\mathrm{NCl}-$ Executive Plaza North, 6130 Executive Boulevard, Bethesda, MD 20892, USA.

S. P. Buchbinder and E. Vittinghoff, San Francisco City Clinic, Department of Public Health, 24 Van Ness Avenue, San Francisco, CA 94102-8033, USA

E. Gomperts, Childrens Hospital Los Angeles, 4650 Sunset Boulevard, Los Angeles, CA 90027, USA.

S. Donfield, New England Research Institute, Incorporated, 9 Galen Street, Watertown, MA 02172, USA.

D. Vlahov, Department of Epidemiology, The Johns Hop kins School of Hygiene and Public Health, 615 North Wolfe Street, Baltimore, MD 21205, USA.

R. Kaslow, Department of Epidemiology, University of Alabama at Birmingham, 720 South 20th Street, Birmingham, AL 35294-0008, USA.

A. Saah, The Johns Hopkins School of Hygiene and Public Health, 615 North Wolfe Street, Baltimore, MD 21205 USA.

C. Rinaldo, University of Pittsburgh School of Public Health, 4200 5th Avenue, Pittsburgh, PA 15213, USA.

R. Detels, University of California, Los Angeles, Schools of Public Health and Medicine, 10833 Le Conte Avenue Los Angeles, CA 90025-1772, USA.

*These authors contributed equally to this study.

†To whom correspondence should be addressed. symbol CMKBR5) (16), which serves as the principal cellular receptor for RANTES, MIP-1 $\alpha$, and MIP-1 $\beta$, is an efficient coreceptor for macrophage-tropic isolates of HIV-1 (17-22). The closely related CKR2B and CKR3 molecules can also act as coreceptors for some HIV-1 strains $(20,21)$. In addition, Dragic et al. (17) observed that $\mathrm{CD}^{+}{ }^{+} \mathrm{T}$ cells from some HIV-1-exposed individuals who have remained uninfected are relatively resistant to infection, suggesting that a defect in co-receptors or their expression may protect some individuals from infection.

The C-C or $\beta$ chemokine receptors belong to the heterotrimeric GTP-binding protein ( $G$ protein)-coupled receptor superfamily (22-24). The C-C chemokine receptors consist of seven transmembrane domains and typically contain no introns (12$14,16)$. The genes for the C-C chemokines are linked in a cluster on chromosome 17 (24). In contrast, the genes for the receptors are dispersed in the genome as single genes or in small clusters of genes that have related function and sequence (24).

To genetically map the locus encoding fusin and the CKR5 locus, we used genespecific polymerase chain reaction (PCR) primers designed from the sequences of the genes $(13,16)$ to screen a panel of 90 radiation hybrid (RH) DNA samples (25). The $\mathrm{RH}$ panel is designed to retain small segments of the human genome in different combinations so that the map location of new markers is implicated by their concordant occurrence in the panel with previously mapped markers (Fig. 1A) (25). The distribution of RH results indicates that fusin maps to chromosome $2 \mathrm{q} 21$, proximal to the
A

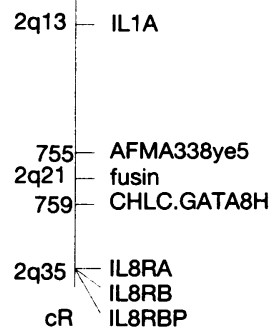

B

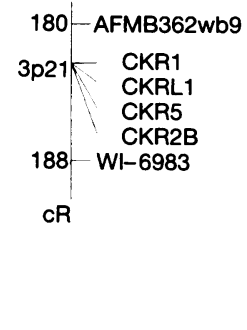

Fig. 1. Mapping of CKR genes. (A) The location of the gene encoding fusin is shown on the map of chromosome 2 in relation to the interleukin- $1 \alpha$ (IL1A) gene and the closely related interleukin-8 receptor $A$ and $B$ (IL8RA, IL8RB) and their pseudogene (IL8RBP). (B) The CKR5 gene was also typed in this $\mathrm{RH}$ panel and is located in the same cluster on chromosomes 3p21 as CKR1. CKR1, C-C chemokine receptor 1; CKRL1, CKR1-like gene; CKR2B, C-C chemokine receptor 2B. Flanking framework markers are shown above and below the mapped genes, and their centirad (cR) distance from the top of the chromosome is shown to the left. AFMA338ye5, CHLC.GATA8H, and AFMB362wb9 are CA repeats, and WI-6983 is the RII subunit of cyclic AMP-dependent protein kinase. Methods are described in (51). 
related interleukin-8 receptor (IL8RA, IL8RB) genes, and distal to the IL-1 and IL-1 receptor (ILI, ILIR) gene cluster (12). CKR5 maps to chromosome $3 \mathrm{p} 21$, very close to the CKRI gene, which we also physically mapped in this analysis (Fig. 1B). CKR2B has been previously shown to be $18 \mathrm{~kb}$ from CKR5 (16) and can therefore also be assigned to 3 p21. These gene-mapping assignments provide additional evidence for the occurrence of chemokine receptor genes in small clusters in different regions of the human genome.

We identified alterations in the CKR5 gene by amplifying portions of the entire coding region, digesting the fragments with Hinf I, and resolving the fragments by a combined single-stranded conformation polymorphism-heteroduplex analysis approach $(26,27)$. DNA from more than 600 individuals (healthy controls, HIV-1 at-risk seronegatives, HIV-1-infected, non-AIDS, and AIDS patients) was typed by this procedure, and eight molecular genetic variants were identified. One of the alterations occurred in $\sim 10 \%$ of the individuals, and this allele was sequenced. This variant contains a 32 -base pair (bp) deletion (CKR5 32$)$ that causes a frame shift at amino acid 185. After this manuscript was submitted, Samson et al. (28) and Liu et al. (29) also described the same CKR5 deletion mutation. The CKR5 32 allele is nonfunctional both as a chemokine receptor and an HIV-1 co-receptor.
The other seven variants we found were all rare and were observed in $\leq 1 \%$ of the individuals studied (30).

Lymphoblastoid B cell lines were established for over 1900 participants who are members of six well-characterized longterm cohorts of hemophiliac, homosexual male, and intravenous drug user risk groups (Table 1) (31-36). Genomic DNA from 156 cell lines derived from Caucasian participants from the DCG and MACS studies was screened by using 170 defined and mapped polymorphic loci (37), including candidate genes (for example, CD4, chemokine SCYA1, HLA-DQA1, TCRA, TCRB, and CKR5), for distortion of allele and genotype frequency among HIV-1-infected versus HIV-1 antibodynegative individuals at risk for exposure to HIV-1. Loci were selected on the basis of available polymorphisms, potential involvement in retroviral infection or pathogenesis, and their genetic location, producing an average 20-centimorgan interval of markers $(37,38)$. The significance level estimated with a $G$ test (39) for each of the 170 loci for the occurrence of genotypic association between HIV-1infected versus HIV-1 antibody-negative individuals is presented in Fig. 2. With the exception of CKR5, none of the loci tested displayed a significant distortion of genotype frequencies among the infected versus uninfected individuals. The genotypic distribution of the two common alleles of
CKR5 [normal or wild type $(+)$ and CKR5 32 deletion] in 738 Caucasian homosexual men displays a highly significant $\left(P=2.0 \times 10^{-5}\right)$ departure from genotypic equilibrium when frequencies among HIV. 1 -infected versus uninfected individuals are examined. Although these 170 markers scan only a portion of the genome for HIV restriction loci, the absence of any association at any of the loci suggests that there is not a major effect on HIV-1 infection from genes close to (within $1 \mathrm{cM}$ of) the test markers. The list includes the HIV receptor (CD4), a $\beta$ chemokine (SCYA1), and several immune function genes. These markers provide negative controls for the result observed with CKR5.

To examine further the role of the CKR5 32 allele in HIV-1 infection, we determined the distribution of alleles and genotypes with genomic DNA from 1955 individuals from the six cohorts listed in Table 1. Each of these studies represents a long-term epidemiological project designed to characterize important variables in HIV-1 infection and disease progression. All cohort participants are in high-risk groups for HIV-1 infection; namely, hemophiliacs potentially exposed to contaminated clotting factor before HIV-1 screening and viral inactivation, sexually active homosexual men, and intravenous drug users. Participants include HIV-1-exposed seronegative individuals, HIV-1-infected AIDS patients, and HIV-1-infected individuals

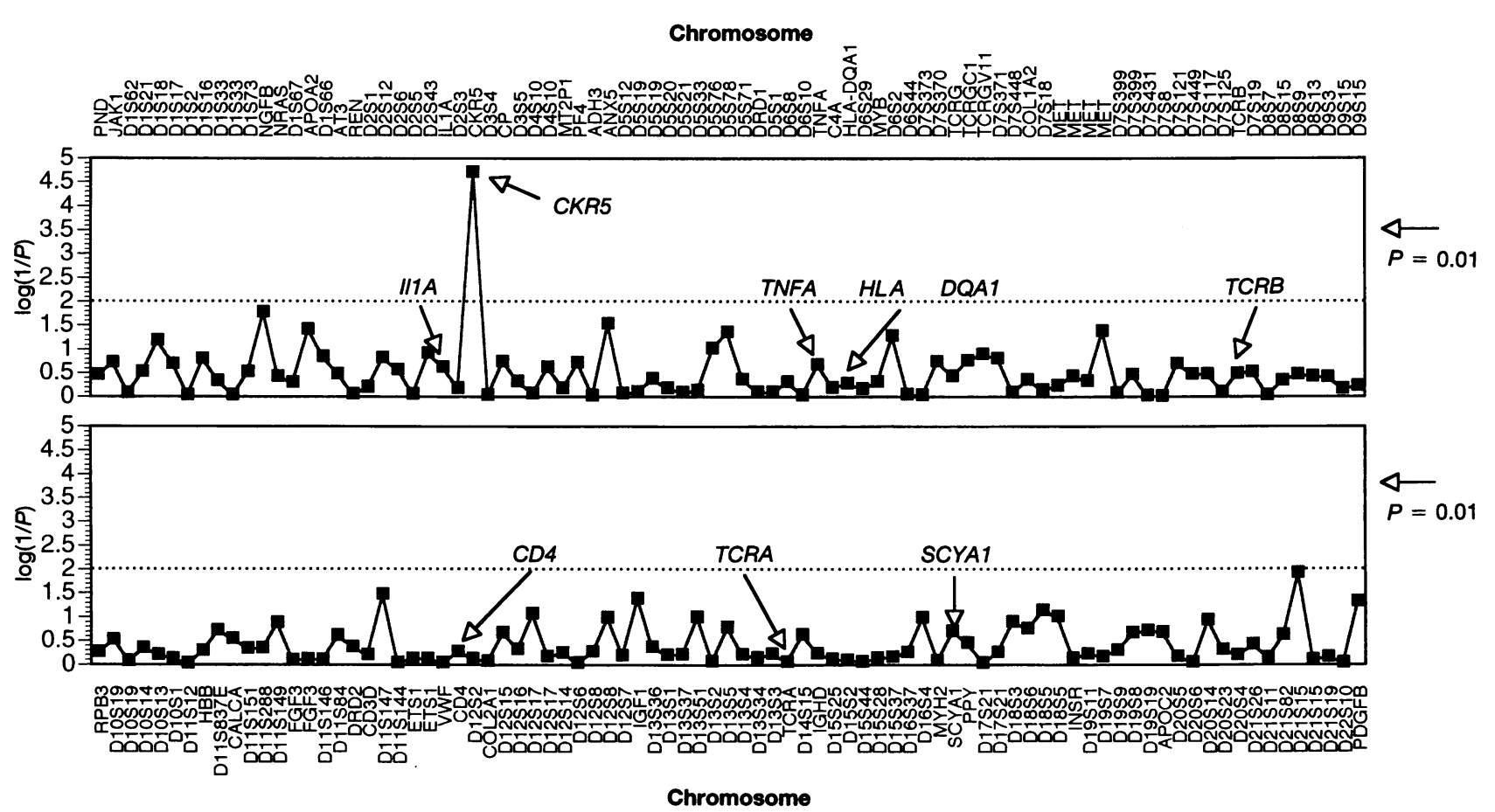

Fig. 2. Genotypic markers 37 and HIV-1 infection [G test (39)]. The significance value of the genotype association for each marker is plotted in physical order along each chromosome. The dotted line corresponds to significance at the $1 \%$ level for individual tests. The right arrow corresponds to an experiment-wide $1 \%$ significance level, estimated with the Bonferroni procedure for multiple samplings [see (43)]. 
studied for various periods who have not progressed to clinical AIDS. Among Caucasian participants in AIDS cohorts, the allele frequency of CKR5 32 was 0.115 $(n=1250)$, whereas the frequency among Caucasians not part of an HIV-1 high-risk group was $0.080(n=143)$. The frequency among African Americans was lower $(0.017 ; n=620)(40)$.

There was no significant difference in the allele frequencies of CKR5 between HIV-1-infected and HIV-1 antibody-negative individuals in any of the cohorts (41); however, a dramatic difference became apparent when the CKR5 genotype distribution was examined (Table 2). There were 17 homozygotes for CKR5 32 found among the individuals tested, all of which were HIV-1 antibody-negative individuals with a high risk for HIV-1 exposure. The association of the $\Delta 32 / \Delta 32$ genotype with HIV1 -negative status is highly significant overall $\left(G=35.0, P=2.5 \times 10^{-8}\right.$; Table 2$)$, as well as in each of three individual cohorts (MACS, SFCC, and MHCS, Table 2) (42). Hence, the CKR5 32 allele appears to con-

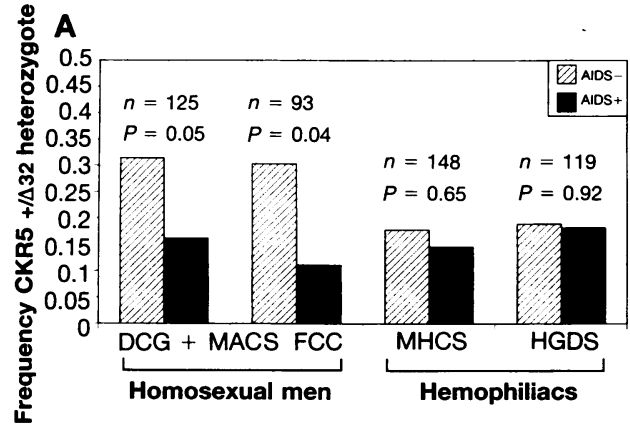

B

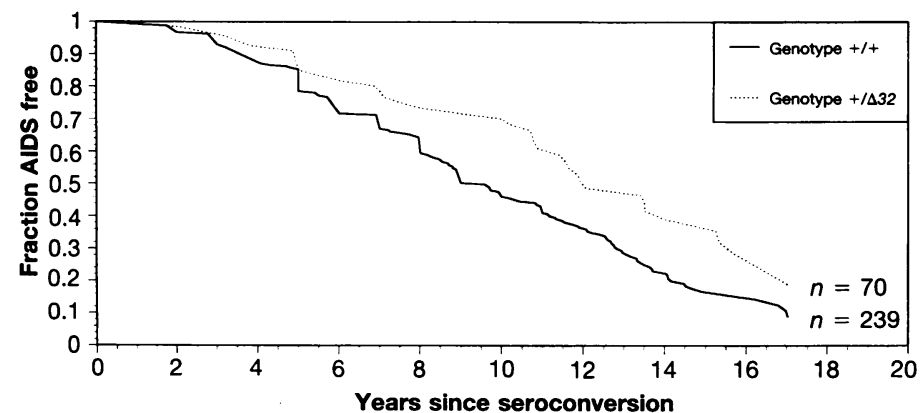

C

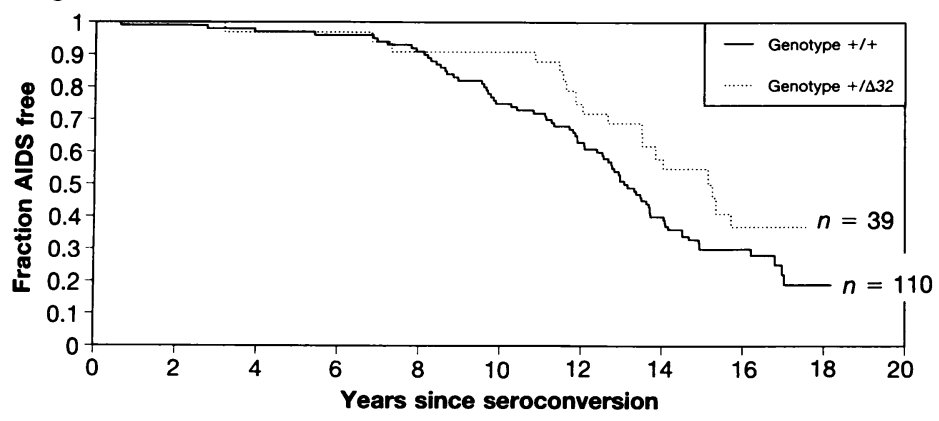

fer a recessive phenotype that is associated with resistance to HIV-1 infection and antibody production.

Although we did not find individuals homozygous for CKR5 32 among 1343 HIV1 -infected patients, there was a sufficient number of heterozygous $(+/ \Delta 32)$ infected patients $(n=195)$ for us to examine the cohorts for an association between CKR5 genotype and different rates of progression to AIDS. The homosexual cohorts, but not the hemophilia cohorts, showed greater than twice the percentage of heterozygotes among long-term nonprogressors compared with rapid progressors (Fig. 3A) (43).

Although there are differences in ascertainment and disease group definition between these groups (for example, there are fewer AIDS cases in the hemophilia cohorts), the frequency of the $+/ \Delta 32$ genotype was not significantly different between rapid progressors and long-term nonprogressors in the hemophilia cohorts when different AIDS endpoints [for example, 1987 AIDS definition (44), CD4 ${ }^{+} \mathrm{T}$ cell counts $\leq 200$, or death by AIDS] were used or the "middle groups" of patients with intermediate criteria were subtracted. The differential response of hemophiliacs versus homosexual men may be related to different routes of transmission, to exposure levels, or to viral load among individuals in different risk groups. Hemophilia patients received large doses of HIV-1-contaminated clotting factors by intravenous injection, whereas sexual transmission would involve HIV-1 infection of mucosal epithelium.

Survival analyses using the clinical 1992 AIDS definition (which includes HIV-1 infection plus either AIDS-defining illness or a decline of $\mathrm{CD}^{+} \mathrm{T}$ cell numbers below 200) (45) were performed for each cohort and for combined cohorts comparing the CKR5 genotypes $(+/+$ and $+/ \Delta 32)$. The results demonstrate that $+/ \Delta 32$ heterozygotes have a delayed progression to AIDS compared with CKR5 $+1+$ homozygotes $\left(\chi^{2}=8.1, P=\right.$ 0.0045 ) (Fig. 3, B and C, and Table 3). After correction for multiple tests, this result is still significant, and the same result is also found when the stricter 1987 AIDS definition (HIV-1 infection plus AIDS-defining pa-
Fig. 3 Analysis of $C K R 5 \Delta 32$ genotypes with reference to progression to AIDS (43) based on previously described clinical disease categories. (A) Frequency of $C K R 5 \Delta 32 /+$ heterozygotes in HIV-1-infected patients: DCG plus MACS, seroconversion patients who progressed to clinical AIDS in $\leq 7$ years compared with patients that did not progress to AIDS in 7 years (8); SFCC, patients that progress to AIDS or CD4 ${ }^{+}$T cell counts $<200$ within 10 years of seroconversion compared with patients without AIDS and CD4 counts $\geq 200$ for 10 or more years (35); MHCS, patients with clinical AIDS in $\leq 10$ years of estimated seroconversion compared with patients without clinical AIDS for more than 10 years after estimated seroconversion dates (32); HGDS, patients with CD4 counts $\leq 200$ before 10 years after estimated seroconversion date compared with patients that had CD4 counts $\geq 200$ for 10 or more years after estimated seroconversion (31). (B) Kaplan-Meier survival distribution curves demonstrating the dependence of disease progression on CKR5 genotype in seroconverters from MHCS, SFCC, and DCG (8, 33-35). A total of 309 patients with known seroconversion dates and for which long-term data were available were followed for development of AIDS [as defined in 1993 definition (45)-progression to an AIDS-defining illness, CD4 counts $\leq 200$, or death]. The HGDS was not included because all patients were seropositive on study entry. The curves were different significantly $\left[x^{2}=8.1,1\right.$ degree of freedom (df), $\left.P=0.005\right]$. Relative hazard equals 0.61 in a Cox proportional hazards model. (C) Kaplan-Meier survival distribution curves demonstrating the dependence of disease progression to AIDS (1993 definition) on the CKR5 genotype, among 148 HIV-1-seropositive members of the SFCC with well-characterized dates of seroconversion who were seen for the study after $1987\left(x^{2}=3.9,1 \mathrm{df}, P=0.05\right)$. A value of $P=0.05$ would not be significant when a correction for multiple tests is applied. Relative hazard, controlling for age, was 0.59 in a Cox proportional hazards model. The endpoint was defined as the first of two consecutive CD4 counts $<200$ or diagnosis of AIDS, with followup censored at the beginning of April 1996. CD4 counts were ascertained at 6- to 12-month intervals from the beginning of recruitment in 1984; AIDS diagnoses have been ascertained by active local surveillance by the San Francisco Department of Public Health as well as regular matches with the Centers for Disease Control and Prevention registry of AIDS cases. 
Table 2. CKR5 genotype distribution among HIV-1-seropositive and HIV-1seronegative individuals in the same risk group. $G$ tests (39) for departure of three observed CKR5 genotypes within HIV-1-infected versus uninfected compared with overall cohort genotypic frequencies are listed. $G$ tests using only Caucasian individuals are given in parentheses in the $G$ and $P$ columns. NC, no Caucasians.

\begin{tabular}{|c|c|c|c|c|c|c|c|c|}
\hline \multirow{2}{*}{ Cohort } & \multirow{2}{*}{ Risk group } & \multirow{2}{*}{$\begin{array}{l}\text { HIV-1 } \\
\text { antibody } \\
\text { status }\end{array}$} & \multirow{2}{*}{ Total } & \multicolumn{3}{|c|}{$\begin{array}{c}\text { Number of patients (\% of total) with } \\
\text { CKR5 genotype }\end{array}$} & \multicolumn{2}{|c|}{ Statistics } \\
\hline & & & & $+/+$ & $+/ \Delta 32$ & $\Delta 32 / \Delta 32$ & $G$ & $P$ \\
\hline \multirow[t]{2}{*}{ DCG } & \multirow[t]{2}{*}{$\begin{array}{l}\text { Homosexual } \\
\text { men }\end{array}$} & $\begin{array}{l}\text { Positive } \\
\text { Negative }\end{array}$ & $\begin{array}{l}137 \\
212\end{array}$ & $\begin{array}{ll}118 & (86) \\
175 & (83)\end{array}$ & $\begin{array}{l}19(14) \\
33(16)\end{array}$ & $\begin{array}{ll}0 & (0) \\
4 & (2)\end{array}$ & & \\
\hline & & Total & 349 & 293 & 52 & 4 & $2.0(1.6)$ & $0.38(0.44)$ \\
\hline \multirow[t]{2}{*}{ MAC } & \multirow[t]{2}{*}{$\begin{array}{l}\text { Homosexual } \\
\text { men }\end{array}$} & $\begin{array}{l}\text { Positive } \\
\text { Negative }\end{array}$ & $\begin{array}{r}265 \\
24 \\
\end{array}$ & $\begin{array}{rr}201 & (76) \\
14 & (58) \\
\end{array}$ & $\begin{array}{r}64(24) \\
6(25) \\
\end{array}$ & $\begin{array}{lr}0 & (0) \\
3(17) \\
\end{array}$ & & \\
\hline & & Total & 289 & 215 & 70 & 3 & $9.9(9.6)$ & $0.007(0.008)$ \\
\hline \multirow[t]{2}{*}{ SFCC } & \multirow[t]{2}{*}{$\begin{array}{l}\text { Homosexual } \\
\text { men }\end{array}$} & $\begin{array}{l}\text { Positive } \\
\text { Negative }\end{array}$ & $\begin{array}{r}150 \\
42\end{array}$ & $\begin{array}{rr}110 & (73) \\
34 & (81)\end{array}$ & $\begin{array}{r}40(27) \\
5(12) \\
\end{array}$ & $\begin{array}{ll}0 & (0) \\
3 & (7) \\
\end{array}$ & & \\
\hline & & Total & 193 & 145 & 45 & 3 & $9.2(7.9)$ & $0.01(0.02)$ \\
\hline \multirow[t]{2}{*}{ HGDS } & \multirow[t]{2}{*}{ Hemophiliacs } & $\begin{array}{l}\text { Positive } \\
\text { Negative }\end{array}$ & $\begin{array}{l}133 \\
104\end{array}$ & $\begin{array}{rr}106 & (80) \\
87 & (84)\end{array}$ & $\begin{array}{l}27(20) \\
17(16)\end{array}$ & $\begin{array}{ll}0 & (0) \\
0 & (0)\end{array}$ & & \\
\hline & & Total & 237 & 193 & 44 & 0 & $0.62(0.1)$ & $0.73(0.85)$ \\
\hline \multirow[t]{2}{*}{ MHCS } & \multirow[t]{2}{*}{ Hemophiliacs } & $\begin{array}{l}\text { Positive } \\
\text { Negative }\end{array}$ & $\begin{array}{l}192 \\
191 \\
\end{array}$ & $\begin{array}{ll}156 & (81) \\
158 & (82) \\
\end{array}$ & $\begin{array}{l}36(19) \\
26(14)\end{array}$ & $\begin{array}{ll}0 & (0) \\
7 & (4) \\
\end{array}$ & & \\
\hline & & Total & 383 & 314 & 62 & 7 & $8.0(8.9)$ & $0.02(0.01)$ \\
\hline \multirow[t]{2}{*}{ ALIVE } & \multirow[t]{2}{*}{$\begin{array}{l}\text { Intravenous } \\
\text { drug users }\end{array}$} & $\begin{array}{l}\text { Positive } \\
\text { Negative }\end{array}$ & $\begin{array}{r}466 \\
39 \\
\end{array}$ & $\begin{array}{r}457(98) \\
39(100) \\
\end{array}$ & $\begin{array}{ll}9 & (2) \\
0 & (0) \\
\end{array}$ & $\begin{array}{ll}0 & (0) \\
0 & (0) \\
\end{array}$ & & \\
\hline & & Total & 505 & 496 & 9 & 0 & $0.1(\mathrm{NC})$ & 0.77 (NC) \\
\hline \multirow[t]{2}{*}{ All cohorts } & \multirow{2}{*}{$\begin{array}{l}\text { Homosexual } \\
\text { men and } \\
\text { hemophiliacs }\end{array}$} & $\begin{array}{l}\text { Positive } \\
\text { Negative }\end{array}$ & $\begin{array}{r}1343 \\
612 \\
\end{array}$ & $\begin{array}{rr}1148 & (85) \\
508 & (83) \\
\end{array}$ & $\begin{array}{r}195(15) \\
87(14) \\
\end{array}$ & $\begin{array}{rr}0 & (0) \\
17 & (3) \\
\end{array}$ & & \\
\hline & & Total & $\overline{1955}$ & $\overline{1656}$ & $\overline{282}$ & $\overline{17}$ & $35.0(33.3)$ & $\begin{array}{l}2.5 \times 10^{-8} \\
\left(5.8 \times 10^{-8}\right)\end{array}$ \\
\hline
\end{tabular}

thologies) is used (Table 3). The contribution of the individual cohorts to the combined analysis in Fig. 3B is shown in Table 3. The same trend (longer survival of $+/ \Delta 32$ individuals) was observed in all cohorts except DCG, which only contributes 43 pa-

Table 3. Survival analysis for progression to AIDS among HIV-1-infected seroconverters of individual cohorts. The number of seroconverters is shown for each cohort, broken down into homozygous wild-type $(+/+)$ and heterozygous $(+/$ $\Delta 32)$ individuals. The $x^{2}$ and uncorrected with $1 \mathrm{df}$ $P$ values for a difference between the $+/+$ and $+/ \Delta 32$ survival curves were computed for each cohort using both 1987 and 1992 AIDS definitions $(44,45)$.

\begin{tabular}{llllll}
\hline Cohort & \multicolumn{2}{c}{ Genotype } & & & \\
\cline { 2 - 3 } & $+1+\quad+/ \Delta 32$ & & & & \\
& & & & \\
\hline
\end{tabular}

1987 AIDS definition as survival outcome

\begin{tabular}{|c|c|c|c|c|c|}
\hline MACS & 91 & 24 & 115 & 1.5 & 0.22 \\
\hline SFCC & 110 & 39 & 149 & 1.2 & 0.27 \\
\hline MHCS & 78 & 17 & 95 & 0.83 & 0.36 \\
\hline DCG & 33 & 9 & 42 & 0.01 & 0.93 \\
\hline All & 312 & 89 & 401 & 4.0 & 0.04 \\
\hline \multicolumn{6}{|c|}{1992 AIDS definition as survival outcome } \\
\hline SFCC & 110 & 39 & 149 & 3.36 & 0.07 \\
\hline $\mathrm{MHCS}$ & 96 & 21 & 117 & 3.98 & 0.05 \\
\hline CG & 33 & 10 & 43 & 0.04 & 0.84 \\
\hline All & 239 & 70 & 309 & 8.1 & 0.00 \\
\hline
\end{tabular}

tients. These data suggest that the singlegene effect of CKR5 32 may be dominant and that interaction with other genes or the environment or both is necessary to prolong AIDS onset in infected patients. Epistatic analyses with other variables (such as age and HLA type) are required to more accurately characterize this effect.

Our data strongly suggest that the CKR5 protein plays a regulatory role in HIV-1 infection as well as in the rate of progression of the disease. Individuals homozygous for a deletion in CKR5 appear to have a greatly reduced risk of HIV-1 infection. The simplest explanation for the gene action is that homozygous recessive $\Delta 32 / \Delta 32$ individuals avoid infection because of the absence of a functional CKR5 co-receptor. Alternatively, heterozygotes $(+/ \Delta 32)$ can be infected, but the gene dosage effect of the requisite HIV-1 co-receptor limits virus spread in infected patients [and virus load is correlated to AIDS progression $(46,47)]$, postponing AIDS onset.

Further studies of homozygous $\Delta 32 / \Delta 32$ individuals to determine whether they have a memory $\mathrm{T}$ cell response to the virus, which would indicate that they were infected and mounted a successful immune response, would be enlightening. It is possible that $\Delta 32 / \Delta 32$ individuals could become infected by certain strains of HIV-1 (for example, syncytium- forming viruses or isolates adapted to CD4fusin receptor entry), or by certain routes of infection (for example, transfusion). However, we have observed $\Delta 32 / \Delta 32$, HIV-1-seronegative individuals in homosexual, hemophiliac, and intravenous drug-use cohorts, suggesting that this genotype confers broad protection against infection.

In addition to CKR5 32 , we also found unique SSCP conformers in other patients, several of whom were long-term nonprogressors (30). We speculate that at least some of these alleles also disrupt CKR5 function and inhibit the spread of HIV-1 or progression to AIDS. The entire coding region of CKR5 should be screened in additional HIV-1-seronegative, long-term nonprogressors and in rapid progressors to identify other CKR5 variants. The CKR2B and CKR3 proteins are also capable of acting as receptors for macrophage-tropic HIV-1 strains $(19,20)$. Alterations in these genes, as well as in fusin, may also influence HIV-1 infection or progression.

The identification of CKR 5 as a critical molecule for HIV-1 infection suggests alternative antiviral therapies. Native or altered forms of the CKR5 ligands (RANTES, MIP-1 $\alpha$, MIP-1 $\beta$ ) could potentially block or delay infection. Alternatively, fragments of the HIV-1 env protein product that bind to CKR 5 may be effective in 
competing for HIV-1 binding sites on $\mathrm{CKR}^{+}$cells. Drugs or gene-targeting constructs that down-regulate or inactivate CKR5 may have therapeutic value. It is also possible that transplantation of bone marrow stem cells from a $\Delta 32 / \Delta 32$ donor could have therapeutic benefit. AntiCKR5 therapies may augment the effectiveness of other anti-HIV-1 compounds already in use.

A large difference in the frequency of the CKR5 32 allele was observed between Caucasians (0.11) and African Americans (0.017). If widespread screens of African racial groups affirm the absence of the CKR5D32 allele as has been reported in a survey of 124 Africans (29), it may be that CKR5 $\Delta 32$ is a recent mutation that occurred on the Caucasian lineage subsequent to divergence from the African-Caucasian ancestor estimated to have occurred 150,000 to 200,000 years ago (48). The frequency observed in African Americans could be entirely due to admixture from Caucasian gene flow in the New World, estimated to be as high as $30 \%$ (49). The relatively high prevalence of the inactivating CKR5 $\Delta 32$ allele is suggestive of an historic selective pressure among Caucasians, perhaps by another pathogenic virus or parasite, that also used the CKR 5 receptor as an entry point. Such historic increases in recessive disease mutations due to epidemiologic agents have been suggested for other hereditary diseases, including sickle cell anemia, thalassemia, and lysosomal storage diseases (50).

Liu et al. demonstrated that the wellcharacterized EU2 and EU3 patients (29) are CKR5 $\Delta 32$ homozygotes and that no functional CKR 5 protein is present on the cell surface. In addition, they showed that cells from CKR5 32 homozygotes fail to respond to MIP-1 $\alpha$ in vitro. Samson et al. found no CKR5 32 homozygotes among 723 HIV-1-infected individuals and a rather low frequency for the CKR5 32 allele (0.054) in HIV-1-infected patients, leading them to suggest that $+/ \Delta 32$ heterozygotes may be less susceptible to infection than CKR5 $+/+$ individuals (28). Our results (Table 2) did not reveal a difference in CKR5 $\Delta 32$ allele frequency in HIV-1-infected (0.11) compared with HIV-1-negative exposed (0.12) individuals. Our data suggest that in the heterozygous state, the CKR5 $\Delta 32$ allele does not markedly affect susceptibility to infection but does postpone progression to AIDS in infected patients.

\section{REFERENCES AND NOTES}

1. R. May and R. Anderson, Infectious Disease in Humans (Oxford Univ. Press, New York, 1995).

2. S. S. Morse, Ed., Emerging Viruses (Rockefeller Univ. Press, New York, 1993)
3. T. I. A. Sorensen, G. G. Nielsen, P. K. Andersen, T. W. Teasdale, N. Engl. J. Med. 318, 727 (1988)

4. A. G. Motulsky, Human Genetics: Patterns and Ap proaches (Springer-Verlag, Berlin, 1981).

5. S. Wain-Hobson, Curr. Opin. Genet. Dev. 3, 878 (1993).

6. J. M. Coffin, Science 267, 483 (1995).

7. E. L. Delwart et al., ibid. 262, 1257 (1993).

8. R. A. Kaslow et al., Nature Med. 2, 405 (1996); B. F. Haynes, G. Pantaleo, A. S. Fauci, Science 271, 324 (1996).

9. W. A. Paxton et al., Nature Med. 2, 412 (1996); R. Detels et al., AIDS 10, 102 (1996)

10. F. Cocchi et al., Science 270, 1811 (1995); M. Baier, A. Werner, N. Bannert, K. Metzner, R. Kurth, Nature 378, 563 (1995).

11. Y. Feng, C. C. Broder, P. E. Kennedy, E. A. Berger, Science 272, 872 (1996)

12. B. Federsppiel et al., Genomics 16, 707 (1993)

13. H. Herzog, Y. J. Hort, J. Shine, L. A. Selbie, DNA Cell Biol. 12, 465 (1993).

14. H. Nomura, B. W. Nielsen, K. Matsushima, Int. Immunol. 5, 1239 (1993)

15. P. J. Madden et al., Cell 47, 333 (1986).

16. C. Combadiere, S. K. Ahuja, H. L. Tiffany, P. M Murphy, J. Leukocyte Biol. 60, 147 (1996); M. Samson, O. Labbe, C. Mollereau, G. Vassart, M. Parmentier, Biochemistry 35, 3362 (1996).

17. T. Dragic et al., Nature 381, 667 (1996).

18. G. Alkhatib et al., Science 272, 1955 (1996)

19. H. Choe et al., Cell 85, 1135 (1996).

20. B. J. Doranz et al, ibid. P. 1149.

21. H. Deng et al., Nature 381, 661 (1996).

22. P. M. Murphy, Annu. Rev. Immunol. 12, 593 (1994)

23. K. Neote, D. DiGregorio, J. Y. Mak, R. Horuk, T. J. Schall, Cell 72, 415 (1993)

24. C. J. Raport et al., J. Leukocyte Biol. 59, 18 (1996)

25. M. A. Walter, D. J. Spillett, P. Thomas, J. Weissenbach, P. Goodfellow, Nature Genet. 7, 22 (1994).

26. M. White, M. Carvalho, D. Derse, S. J. O'Brien, M Dean, Genomics 12, 301 (1992); M. Ravnik-Glavac, D. Glavac, M. Dean, Hum. Mol. Genet. 3, 801 (1994).

27. M. Orita, Y. Suzuki, T. Sekiua, K. Hayashi, Genomics 5, 874 (1989)

28. M. Samson, Nature 382, 722 (1996)

29. R. Liu et al., Cell 86, 367 (1996).

30. Eight $C K R 5$ variant alleles were found. These include the $\Delta 32$ deletion; a variant that occurred as a heterozygote in 15 individuals of $\sim 600$ screened by SSCP four variants found as heterozygous in single individ uals that were HIV-1 infected, but had not progressed to AIDS after 7 to 10 years; and two variants in HIV-1-infected individuals that had not been followed for long term as yet. Preliminary sequence analysis revealed missense alterations in codons for conserved amino acids in three of the variants.

31. M. W. Hilgartner et al., Am. J. Pediatr. Hematol. Oncol. 15, 208 (1993).

32. J. J. Goedert et al., N. Engl. J. Med. 321, 1141 (1989)

33. J. J. Goedert et al., Am. J. Epidemiol. 121, 629 (1985)

34. R. A. Kaslow et al., ibid. 126, 310 (1987); J. Phair et al., J. AIDS 5, 490 (1992); R. Detels et al., ibid. 7. 1263 (1996)

35. S. P. Buchbinder, AIDS 8, 1123 (1994).

36. D. Vlahov et al., NIDA Research Monograph Series 103 (Public Health Service, Alcohol and Drug Abuse Administration, Washington, DC, 1991)

37. M. Dean et al., Am. J. Hum. Genet. 55, 788 (1994)

38. J. C. Stephens, D. Briscoe, S. J. O'Brien, ibid., p. 809.

39. The $G$ test is a likelihood ratio test that is equivalent to the $\chi^{2}$ test but is less sensitive to very low "expected" values [J. H. Zar, Biostatistical Analysis (Prentice-Hall, Englewood Cliffs, NJ, 1984), p. 71]. With the Williams correction, $G$ values are comparable with $x^{2}$ values [R. R. Sokal and F. J. Rohlf, Biometry (Freeman, New York, 1981)]. For all significant values, a Fisher's exact test gave similar results.

40. The ALIVE cohort is composed of African American intravenous drug users and includes 496 homozy gous $(+/+)$ and 9 heterozygous $(+/ \Delta 32)$ individuals. With so few individuals with the CKR5 32 allele, the ALIVE cohort was not included in subsequent com- putations. Although behavioral variables are probably more important, the relatively low CKR5 $\Delta 32$ allele frequency in African Americans may contribute to a higher rate of infection in this ethnic group among intravenous drug users [D. Vlahov et al., Am. J. Epidemiol. 132, 847 (1990)]

41. M. Dean et al., data not shown.

42. A significant reduction in heterozygotes $(+/ \Delta 32)$ was observed among HIV-1-seronegative individuals. This result warrants further study.

43. With the Bonferroni correction for multiple tests (four tests), the individual homosexual cohorts are not significant. When the two homosexual cohorts are combined, although they have different definitions of rapid progression, the result is significant $(P=$ 0.005 ), even after corrections for multiple tests [B. S. Weir, Genetic Data Analysis II (Sinauer, Sunderland, MA, 1996)]

44. Centers for Disease Control, Morb. Mortal. Wkly. Rep. 36 (suppl. 1) (14 August 1987)

45. ibid. 41 (18 December 1992). This publication contains a revised classification system for HIV infection and an expanded surveillance case definition for AIDS among adolescents and adults.

46. J. W. Mellors et al., Science 272, 1167 (1996).

47. T. R. O'Brien et al., J. Am. Med. Assoc. 276, 105 (1996).

48. R. L. Cann, M. Stoneking, A. C. Wilson, Nature 325, 31 (1987).

49. R. Chakraborty and P. E. Smouse, Proc. Natl. Acad. Sci. U.S.A. 85, 3071 (1988).

50. S. J. O'Brien, Curr. Biol. 1, 209 (1991).

51. Radiation hybrid DNAs, obtained from Research Genetics, were amplified for $20 \mathrm{~min}$ in a $10-\mu$ PCR reaction with the following primers: for CKR5, primers CCK5F2 (5'-GGTGGAACAAGATGGATTAT-3') and CCK5R2 (5'-CATGTGCACAACTCTGACTG-3'); for fusin, primers FUSF1 (5' -TGTACGTGTGTCTAGGCAGG-3') and FUSR1 (5'-TGTAGGTGCTGAAATCAACCC-3'); and for CKR1, primers CKRF1 (5'-TCCCACTGCCAAGAACTTG-3') and CKRR1 (5'-TTCCCCAGGATTCCAAGAG-3'). Samples were amplified with 5 units of Taq Gold (Stratagene) in the supplier's buffer in a Cetus 9600 PCR machine with a $58^{\circ} \mathrm{C}$ annealing temperature and loaded onto a $1.5 \%$ agarose gel. Scores for 90 radiation hybrids were recorded, and the results were analyzed by the Whitehead Mapping Server (http://www-genome! wi.mit.edu/cgi-bin/contig/rhmapper.pl) to determine significant linkages onto the framework map. $\mathrm{RH}$ typ ing data is available on request at e-mail address dean@ncifcrf.gov.

52. HGDS investigators: A Willoughby, National Institute of Child Health and Human Development, Bethesda, MD; W. Kesell, Bureau of Maternal and Child Health and Resources Development, Bethesda, MD; D. Mann, Univ. of Maryland; W. Pequegnat, National Institute of Mental Health, Bethesda, MD. The follow ing individuals are the center directors, study coordnators, or committee chairs of the HGDS study: Childrens Hospital, Los Angeles-F. Kaufman, M. Nelson, S. Pearson; The New York Hospital-Cornell Medical Ctr.-M. Hilgartner, S. CunninghamRundles, J. Gertner, I. Goldberg; Univ. of Texas Medical Sch., Houston-W. K. Hoots, K. Loveland, M. Cantini, G. Casterline; NIH, National Institute of Child Health and Human Development, Bethesda, MD-A. Willoughby; New England Research Institutes, Incorporated (Data Coordinating Center), Watertown-S. Donfield, M. A. Maeder; Baylor College of MedicineC. Contant Jr.; Univ. of lowa Hospitals and Clinics, lowa City-C. T. Kisker, J. Stehbens, J. Bale, S. O'Conner; Tulane Univ.-P. Sirois; Children's Hospital of Oklahoma, Oklahoma City - C. Sexauer, $H$. Huszti, S. Hawk, F. Kiplinger; Mount Sinai Medical Ctr., New York City-S. Arkin, A. Forster; Univ. of Nebraska Medical Ctr.-S. Swindells, S. Richard; Univ of Texas Health Science Ctr. San Antonio-J. Mangos, A. Scott, R. Davis; Children's Hospital of Michigan, Detroit-J. Lusher, I. Warrier, K. Baird-Cox; Milton S. Hershey Medical Ctr., Hershey, PA-M. E. Eyster, E. Pattishall, D. Ungar, S. Neagley; Univ. of Indiana, James Whitcomb Riley Hospital for Children-A Shapiro, S. Hatcher: Univ of California-San Diego Medical Ctr.-G. Davignon, P. Rabwin; Kansas 
City Sch. of Medicine, Children's Mercy Hospital-B. Wicklund, A. Mehrhof. MHCS investigators: M. E. Eyster, Milton S. Hershey Medical Ctr., Hershey; M Hilgartner, Cornell Medical Ctr.; A. Cohen, Children's Hospital of Philadelphia; B. Konkle, Thomas Jefferson Univ. Hospital; G. Bray, Children's Hospital National Medical Ctr., Washington, DC; L. Aledort, Mount Sina Medical Ctr., New York City; C. Kessler, George Washington Univ. Medical Ctr.; C. Leissinger, Tulane Medical Sch.; G. White, Univ. of North Carolina; M Lederman, Case Western Reserve Medical School, Cleveland; P. Blatt, Christiana Hospital; M. MancoJohnson, Univ. of Colorado.

53. We are indebted to the children, adolescents, adults, and parents who have volunteered to participate in this study, and to the members of the
Hemophilia Treatment Centers. We thank D. Lomb, S. Edelstein, M. Malasky, T. Kissner, D. Marti, B. Gerrard, A. Hutchinson, M. Weedon, X. Wu, P Lloyd, E. Wendel, M. McNally, R. Boaze, L. Ke nefic, M. Konsavich, C. Stewart, and S. Cevario for technical assistance, and B. Weir, M. Clegg, R Adamson, and R. Gallo for helpful discussions. Computing resources were provided by the Fred erick Biomedical Supercomputing Center. Sup ported by the Bureau of Maternal and Child Health and Resources Development (MCJ-060570), the National Institute of Child Health and Human Development (NO1-HD-4-3200), the Centers for Disease Control and Prevention, the National Institute of Mental Health, and the National Institute of Drug Abuse (DA04334). Additional support has been provided by grants from the National Center for Research Resources (General Clinical Research Centers) of $\mathrm{NIH}$ to the New York Hospital-Cornell Medical Center Clinical Research Center (MO1RR06020), the Mount Sinai General Clinical Research Center, New York (MO1-RR00071), the University of lowa Clinical Research Center (MO1RR00059), and the University of Texas Health Science Center, Houston (MO1-RR02558). The content of this publication does not necessarily reflect the views or policies of the Department of Health and Human Services, nor does mention of trade names, commercial products, or organizations imply endorsement by the U.S. Government.

7 August 1996; accepted 3 September 1996

\section{CD40 Ligand-Dependent T Cell Activation: Requirement of B7-CD28 Signaling Through CD40}

\section{Yiping Yang and James M. Wilson*}

The role of CD40 ligand (CD40L) in the primary activation of T cells is not clear. The cellular and humoral immune responses to adenoviral vectors in a murine model of liver-directed gene transfer were studied to define the mechanisms responsible for CD40L-dependent $T$ cell priming. CD40L-deficient mice did not develop effective cytotoxic $T$ cells to transduced hepatocytes, and $T$ cell-dependent $B$ cell responses were absent. Full reconstitution of cellular and humoral immunity was achieved in CD40L-deficient mice by administration of an activating antibody to CD40 that increased expression of B7.2 on spleen cells. Wild-type mice could be made nonresponsive to vector by administration of antibodies to B7. Thus, CD40L-dependent activation of T cells occurs through signaling of CD40 in the antigen-presenting cell to enhance requisite costimulatory pathways that include $B 7$.

The role of CD40L in humoral immunity is illustrated by the multiple defects in B cell activation that characterize its genetic deficiency in mice and humans, including a failure to form germinal centers, activate memory B cells, and class switch (1). Experiments in knockout mice have implicated CD40L in the antigen-specific priming of T cells, although the precise mechanism by which this occurs is unclear (2). Enhanced susceptibility of CD40L-deficient $\left(\mathrm{CD} 4 \mathrm{~L}^{-1}\right.$ -) mice to leishmania infection is consistent with an important role of this molecule in cellular immunity (3). The relation between CD40L and other T cell costimulatory pathways such as B7-CD28 is unclear; in models of allograft rejection, these signaling pathways appear uncoupled (4).

\footnotetext{
Y. Yang, Institute for Human Gene Therapy and Department of Molecular and Cellular Engineering, University of Pennsylvania Medical Center, Philadelphia, PA 19104, USA.

J. M. Wilson, Institute for Human Gene Therapy and Department of Molecular and Cellular Engineering, University of Pennsylvania Medical Center, and the Wistar Institute, Philadelphia, PA 19104, USA

*To whom correspondence should be addressed at Institute for Human Gene Therapy, Wistar Institute, Room 204, 3601 Spruce Street, Philadelphia, PA 19104-4268, USA.
}

Adenoviral vectors are being tested as a possible approach to gene therapy, but the cytotoxic T lymphocyte (CTL) and B cell responses to the viral proteins and transgene products make this strategy less tenable (5). Activation of $\mathrm{CD}^{+}{ }^{+} \mathrm{T}$ cells to input viral capsid proteins, which requires stimulation through the CD40L-CD40 and B7-CD28 pathways, is necessary for both the $\mathrm{CD} 8^{+} \mathrm{T}$ cell (that is, CTL) and B cell (that is, neutralizing antibody) effects (6- 8). If one could minimize the immune response, the adenovirus becomes a viable option. We have used this well-studied immune response to further elucidate the mechanisms of CD40L-dependent activation of T cells (9).

Infusion of adenovirus missing the early (E1) genes and containing the lac Z gene into C57BL/6 mice led to transgene expression in $93 \%$ of hepatocytes in liver harvested 3 days later that diminished to undetectable levels by day 24 (Table 1). Analysis of $\mathrm{CD}^{+}{ }^{+}$lymphocytes in vitro demonstrated activation of $T$ helper $\left(T_{H}\right)$ cells to viral antigens of both the $T_{H} 1$ [that is, secretion of interferon- $\gamma$ (IFN- $\gamma$ ) and interleukin-2 (IL-2)] and $\mathrm{T}_{\mathrm{H}} 2$ (that is, secretion of IL-4 and IL-10) subsets (Fig. 1A) (10). Chromium release assays showed the presence of
CTLs to viral-infected targets in splenocytes harvested 10 days after gene transfer (Fig. 1B) (10). Infusion of vector stimulated the development of germinal centers $[20.4 \pm 1.5$ per section (11)] and the formation of antiviral antibodies of immunoglobulin $\mathrm{M}$ (IgM), IgG1, and IgG2 isotypes (Fig. 2) that are neutralizing (Table 1).

Similar studies performed in mice genetically deficient in CD40L demonstrated the requirement of CD40L-CD40 interactions in the full spectrum of cellular and humoral immune responses to adenoviral vectors in mouse liver; transgene expression was stable for 24 days in $\mathrm{CD}_{40 \mathrm{O}^{-1-}}$ mice $(82 \%$ of hepatocytes still express lacZ, Table 1), and activation of CTLs to viral-infected cells was markedly blunted (8) (Fig. 1B). CD4 ${ }^{+} \mathrm{T}$ cells harvested 10 days after gene transfer failed to respond to viral antigens; however, the basal secretion of cytokines was increased as compared with that observed in C57BL/6 mice (Fig. 1A). CD40L ${ }^{-1-}$ mice failed to develop germinal centers [that is, no germinal centers were detected in four sections from two mice (11)] or neutralizing antibodies (Table 1). Antiviral IgM was formed, but class switch to IgG1 or IgG2a was virtually absent (Fig. 2).

Several models have been suggested to explain the dependent role of CD40L on T cell priming. A critical question is whether CD40L directly transduces an activating signal to the $\mathrm{T}$ cell at the time of engagement with its receptor CD40, or whether the role of CD40L is indirect, effecting $T$ cell activation through CD40-mediated signaling in the antigen-presenting cell (APC) that leads to enhanced costimulation of downstream pathways. Previous in vivo studies in the CD40L ${ }^{-1-}$ mouse documented a primary defect in $\mathrm{T}$ cell priming to soluble antigens without clarification of the mechanisms (2), although in vitro studies have shown that wild-type but not CD40L-deficient T cells activate costimulatory activity in B cells (12). Activation of CD40L with soluble CD40 in the $\mathrm{CD} 40 \mathrm{~L}^{-1-}$ mice partially reconstituted formation of germinal centers, although isotype switching was not observed (2); thus, 